\title{
Selvforsømmelse, fuldskab og andre beskidte ting i Koranen og tidlig islam
}

\author{
JOHANNE LOUISE CHRISTIANSEN
}

ENGLISH ABSTRACT: This article presents and discusses two cases from the Qur'an and the early Islamic post-qur'anic period that may be relevant to the overall topic of this special issue, Salvation and impurity: 1) The so-called 'drunken' or 'intoxicated' Islamic mystics, here represented by the Persian șüfí al-Husayn b. Manșūr al-Hallāj (d. 922); and 2) the state of ihrām, which is the holy state that a Muslim enters in connection with the minor and major Islamic pilgrimage. Based on the two cases, which I have termed an obvious and an inobvious example of the positive (post)Axial relation between salvation and anomic practice, I propose the analytical distinction between a 'temporary' and 'permanent fetishism with impurity'. Whereas the drunken șüfis seem to pursue a more permanent anomic - and perhaps impure - mode of being, the qur'ānic descriptions of the state of ihrām indicate a temporary and controlled exit from and entry back into the normal system. I argue that such a negotiation, and ultimately archaic solution, could be a result of the Qur'än being a complex, conflictual, and tension-filled post-Axial compromise from its very beginning.

DANSK RESUMÉ: I denne artikel præsenterer og diskuterer jeg to cases fra henholdsvis Koranen og den tidlige islamiske post-koraniske periode som kan være relevante for dette temanummers overordnede tema): 1) De såkaldte 'fulde' eller 'berusede' islamiske mystikere repræsenteret her af den persiske șüfì al-Husayn b. Manșūr al-Hallāj (d. 922); og 2) ihrām-tilstanden, som er den hellige tilstand man som muslim indtræder $i$ i forbindelse med den lille og store islamiske pilgrimsfxrd. Med udgangspunkt $i$ de to cases, som jeg har kaldt et oplagt og et uoplagt eksempel på en positiv (post-)aksial forbindelse mellem frelse og anomisk prasisk, foreslår jeg den analytiske skelnen mellem en 'temporær' og en 'permanent urenhedsfetichisme'. Hvor de fulde süfier synes at søge en mere permanent anomisk - og måske uren - situation, er de koraniske beskrivelser af ihrāmtilstanden en temporær og kontrolleret exit fra og entry tilbage til det normale system. Jeg argumenterer for, at en sådan forhandling, og i sidste ende arkaisk løsning, kan skyldes at Koranen allerede fra sin begyndelse var et komplekst, konfliktuelt og spændingsfyldt post-aksialt kompromis. 
KEYWORDS: The Qu'ran; early islam; sufisme; salvation; anomy; impurity; post-axial religion

\author{
Dette er en ædel Koran \\ $i$ et velbevaret skrift, \\ som kun de rene kan berøre \\ nedsendt fra alverdens Herre. (K 56:77-80) ${ }^{1}$
}

Jeg gik ud til Ahmad b. Hanbals grav (må Gud være ham barmhjertig) en måneklar nat. Langt vak fra hvor jeg stod så jeg en mand med ansigtet vendt mod bederetningen. Jeg kom tættere på ham uden at han opdagede det, det var en grædende al-Husayn b. Manșūr [al-Hallāj]. Han sagde: "Du som har beruset mig med Din kærlighed og som har lamslået mig på Din nærheds slette. Du er den Ene, isoleret i evighed, den Ene som alene er grundfxstet på sandhedens trone [...]. Jeg bønfalder Dig, ved denne indvidede jord, at Du ikke afviser mig for efter Du har bortrevet mig fra mig selv, og at Du ikke tvinger mig til at se min sjel igen efter Du har sløret den for mig. Mangedobl mine fjender $i$ Dit land og dem som ønsker at dræbe mig." Da han fornemmede min tilstedevarelse, vendte han sig, grinede, og sagde: "Abū Hasan, dette stadie som jeg befinder mig i er det forste stadie for aspiranter." Af lutter forbavselse sagde jeg: "Mester! Hvis dette er aspiranternes forste stadie, hoad sker der så med ham som er på stadiet over?" Han svarede: "Jeg løj! Dette er det første stadie for dem som overgiver sig til Gud. Nej, jeg løj igen! Dette er det første stadie for de vantro." Så udstødte han tre høje skrig og faldt, blodet strømmende fra hans hals. Han gjorde tegn til at jeg skulle gå, så jeg forlod ham dér. Da jeg så ham næste morgen i Manșūr-moskeen [i Baghdad], tog han min hånd, førte mig til et hjørne af moskeen og sagde: "Ved Gud! Du må ikke fortælle nogen hvad $d u$ så mig gøre $i$ går!" (anekdote om den persiske mystiker alḤusayn b. Manșūr al-Ḥallāj (d. 922), min oversættelse fra Ernst $(1985,67-68))$.

\title{
Indledning
}

Koranen er forholdsvis (og ikke overraskende) optaget af spørgsmålet om renhed og urenhed. For eksempel er ovenstående passage (K 56:77-80) - den eneste passage i Koranen der synes at omtale renhedsregler for tekstens materielle form - blevet omfattende diskuteret i den islamiske eksegetiske tradition: Hvem er 'de rene' og hvem udelukker kategorien 'de rene' her? ${ }^{2}$ Rituel renhed giver blandt andet adgang til et af den koraniske religions vigtigste ritualer, bønnen (K 4:43; 5:6), og urenhed er i den henseende problematisk (der findes dog stadig diverse dispensationer fra en sådan

1 Igennem artiklen angives suratitler og korancitater i Ellen Wulffs oversættelse.

2 Jf. Cook 2000; Zadeh 2008. Koranens materialitet er generelt et understuderet emne og koranforskningen har endnu ikke fået øjnene op for 1980ernes 'materielle vending' (Bräunlein 2016, 266). For et studie af Koranen som fysisk genstand i dansk-muslimsk religiøs praksis, se Christiansen \& Jensen, under udarbejdelse. 
problematik, jf. Christiansen, under udarbejdelse; Hoffmann og Christiansen, under udgivelse $(a, b)$, se også nedenfor). Urenhed i Koranen skal dog ikke forstås som noget farligt, det er i hver tilfælde ikke noget der smitter (som fx i den Hebraiske Bibel, jf. Num 19 og Lundager Jensen 2018. Se også Reinhart 1990, 6, 14ff.; Douglas 1966). I Koranen er urenhed et resultat af menneskets natur og af den socio-historiske verden, som teksten har sin oprindelse i (hvorfor fx svinekød anses som urent, jf. Reinhart 1990, 7ff.). Én ting er rituel urenhed og i Koranen synes denne ikke at være sidestillet med en faktisk fysisk urenhed eller usoignerethed. For eksempel kan en troende, hvis han eller hun befinder sig et sted uden vand, udføre den rituelle renselse (wudiu') med sand eller fint jord (et ritual kendt som tayammum, se K 4:43 citeret nedenfor). Denne dispensation fra brugen af vand indikerer både at rituel renhed ikke som sådan handler om hygiejne og Koranens oprindelige ørkenkontekst.

Selvom hygiejne måske ikke indgår direkte i Koranens og den senere islams rituelle renhedskompleks er generel kropspleje noget der har optaget den islamiske tradition. Denne interesse kan eksemplificeres i det (problematiske) teologiske begreb om fitra, menneskets oprindelige skabte form, ofte forstået som religiøs disposition mod islam (hvorfor nogle muslimske konvertitter kalder sig for revertitter, da de ifølge denne ide vender tilbage til deres oprindelige natur) (Macdonald, "Fițra"). Fițra, som en slags primordial natur, synes at blive nævnt en enkelt gang i Koranen, nemlig i K 30:30. Det er dog især i den senere profetiske litteratur (hadith-litteraturen) at termen knyttes til praksisser indebærende kropspleje. Her argumenteres det, at det at leve op til (mandlig) fitra medfører en opmærksomhed på, for eksempel, moustachetrimning, kønshårbarbering og negleklipning:

' $\overline{\mathrm{A}}$ ' isha fortalte: Profeten [...] sagde: Ti handlinger er i henhold til fitra: At trimme moustache, at lade skægget gro, at bruge tandstik, at snuse vand i næsen, at klippe negle, at vaske fingerleddene, at plukke hår fra armhulen, at barbere kønshår og at rense ens private dele med vand [...] (min oversættelse fra Șạịh Muslim, Bogen om Renselse, 2, hadith 71)

Hygiejne og kropspleje var således noget muslimer forholdsvis tidligt beskæftigede sig med og de ovennævnte soignerende handlingers udførelse blev forstået som en (om end lille og detaljeret) del af menneskets oprindelige pagt med Gud.

Emnet for dette temanummer, Forløsning igennem urenhed (anomisk praksis), er ikke tydeligt tilstede i den koraniske tekst. ${ }^{3}$ Der er ingen umiddelbare urene eller anomiske praksisser beskrevet, som kan bane vejen til frelse. ${ }^{4}$ Der synes dog at være en del eksempler på anomisk praksis i den tidlige islamiske periode, men om disse er karakteriseret af urenhed som ideal kan diskuteres. Derfor vil denne artikel i høj grad have form som en trial-and-error-proces, dvs. en præsentation og efterfølgende diskussion af materiale, som måske/måske ikke kan være relevant i forhold til det overordnede tema. Jeg vil koncentrere mig om to cases, én fra mit primære forskningsområde, ko-

3 For en introduktion til emnet og nummeret som helhed, se Lundager Jensens artikel i dette nummer af Religionsvidenskabeligt Tidsskrift, s. 7-29.

4 Jeg følger her Durkheims basale definition af anomi som 'normløshed' (Durkheim 1984 (1893), xx). 
ranstudier, om den urenhed eller kropslige upleje som man nødvendigvis bliver udsat for i ihrām, den hellige tilstand som en muslim skal være i i forbindelse med hajj eller 'umra (den lille og store islamiske pilgrimsfærd), og én fra den tidlige formative periode af islam, om de såkaldte 'berusede' eller 'fulde' șūfīer. Anekdokten citeret ovenfor omhandler en af de mest kendte șūfī-lærde, nemlig al-Ḥusayn b. Manșūr alHallāj, som udøvede sådanne beruselsespraksisser. Denne tidlige mystiker vil være mit fokus i den anden case. De to cases har jeg valgt at kalde henholdsvis 'et uoplagt' og 'et oplagt' eksempel på frelse gennem anomisk (og måske uren) praksis.

Lighedstegnet mellem frelse og urenhed er knyttet til de teoretiske begreber aksetidsreligion og askese. ${ }^{5}$ Med den aksiale vending synes der at ske et skift i forhold til tanken om urenhed. Her blev det, der i det arkaiske skulle undgås, noget der skulle søges og påtages. Med andre ord, igennem den tidligere farlige og forbudte urenhed kunne frelse nu opnås. Den positive forbindelse imellem de to tidligere absolut adskilte begreber var et aksialt ideal, men naturligvis - som idealer nu er - ikke noget der kunne gennemføres i sin totalitet. Allerede fra begyndelsen var den meste praksis, der nøje knyttede forløsning og urenhed sammen, formentlig udtryk for nødvendige kompromisser. Nogle ting skulle stadig undgås. Det er derfor væsentlig at tale om grader af urenhedsekstremitet, grader som formentligt var omvendt proportionelle med antal af tilhængere, samt med tiltrækning- og fastholdelsesskraft af det gældende system (jf. Rappaport 1979, 145-72): Jo mere ekstremt et lighedstegn mellem urenhed og frelse blev, jo mere elitært og eksluderende blev systemet. Ville man, for eksempel, prøve at konsolidere sig som en massereligion, måtte der findes en tydelig balance i forhold til denne radikale og destabiliserende (i hvert tilfælde i lyset af en arkaisk fortid) tanke. En sådan balancesøgen skete igennem en naturlig re-arkaisering, hvor man vendte tilbage til en tydeligere undgåelse af det urene (jf. Bellah 2011, 523; Lundager Jensen 2013, 28ff.). I slutningen af denne artikel vil jeg derfor foreslå den analytiske skelnen mellem en 'temporær' og en 'permanent urenhedsfetichisme'.

Revisions- og kompromisstrategier er centrale for studiet af Koranen og den tidlige islam, da disse allerede synes at være en udviklet moderering af den positive aksiale forbindelse mellem anomisk praksis og frelse (Christiansen, under udgivelse). Måske har den koraniske religion, som det forholdsvis sene helligskrift det er (den traditionelle fortælling placerer Koranens oprindelse i 600-tallets Arabien), ${ }^{6}$ taget ved lære af andre og tidligere religioner, som den udviser et klart forhold til (fx K 5:12-13, 72-73). Den koraniske tekst indeholder således flere tilfælde af moderation eller midtersøgen, eksemplificeret i ideen om islam som 'et fællesskab midt imellem' (ummatan wasațan; K 2:143), her ofte tolket som en religion imellem kristendom og jødedom (Kamali 2015; Christiansen, under udarbejdelse; Mazuz 2012; Maghen 2012). Eller i et vers som det følgende, der taler om den bedste måde at fremsige bønnen på:

Sig: “Påkald Gud! Eller påkald Den Barmhjertige! Han har krav på de skønneste navne,

5 Se igen Lundager Jensens introduktionsartikel og Religionsvidenskabeligt Tidsskrift, temanummeret 64, 2016, samt naturligvis Bellah \& Joas 012); Bellah 2011, 2005; Jaspers 1949. Se også min kommende artikel om askese (Christiansen, under udarbejdelse).

6 Koranens oprindelse, kodificering og kanonisering diskuteres stadig inden for koran- og islamstudier. For to alternative teser om tekstens tilblivelse, se Wansbrough 1977; Crone \& Cook 1977. 
hvad I end kalder Ham. ${ }^{7}$ Tal ikke for højt, når du beder, men heller ikke for lavt (wa-lā tajhar bi-șalātika wa-lā tukhāfit bihā). Prøv at finde en mellemvej (wa-btaghi bayna dhālika sabīlan)!" (K 17:110).

Jeg vil vende tilbage til Koranens ekstremismekritik og modereringsstrategier nedenfor og her begynde med det mere oplagte eksempel på en anomi=urenhed=forløsningstendens fra den tidlige post-koraniske islam.

\section{Et oplagt eksempel}

Et umiddelbart og oplagt eksempel på anomisk praksis inden for tidlig islam med forløsning som mål, og som måske har noget med urenhed at gøre, er de såkaldte fulde eller berusede șūfīer. Kategoriseringen mellem henholdsvis 'fulde' eller 'berusede' (ofte kaldet sukr på arabisk) og 'ædru' (sahw) șūfier opstod formentlig tidligt inden for den islamiske tradition (Mojaddedi 2003; Knysh 2000, 68ff.). Typologiens fastsættelse bliver dog ofte tilskrevet den væsentlig senere persiske mystiker 'Alī alHujwīrī (d. ca. 1074) og hans populære værk om sufisme, Kashf al-mahjūb ('Afsløringen af det skjulte'). Selvom forskere og lærde inden for både islamforskningen og sufismen ofte har forstået terminologien metaforisk - som beruselse af Guds kærlighed (jf. anekdoten citeret før artiklens indledning) - kan det stadig diskuteres om der har været faktisk fuldskab involveret. ${ }^{8}$ Såkaldt 'vinpoesi' er ikke unormalt inden for den islamiske tradition, hvor to kendte eksempler er den arabiske poet fra den 'abbāsidiske periode, Abū Nuwās (d. ca. 815) og den persiske poet og grundlægger af șūfī-ordenen Mawlawiyya, Jalāl al-Dīn Rūmī (d. 1273) (jf. fx Ahlwardt 1861; Ritter \& Bausani, "Djalāl al-Dīn Rūm̄̄”). Ligemeget hvad er det vigtigt at pointere, at kategorierne (sukr og sahw) altid betegner to forskellige former for ekstatisk erfaring inden for islamisk mystik. Et af hovedspørgsmålene for den islamiske șūfī-tradition har derfor været, hvilken af de to erfaringer der vurderes højest (cf. Mojaddedi 2003). Det overordnede formål med dem begge er at opnå en forening med Gud, det der inden for sufisme betegnes med begrebsparret fan $\bar{a}$ ' 'forsvinden (i Gud)' og baqa ' 'forbliven (i Gud)' (jf. fx Ohlander 2014).

Typologien om de berusede versus de ædru șūfīer har siden al-Hujwīrīs tid været brugt som kontrasterende termer for ekstrem versus konservativ sufisme. Imidlertid er det ikke alle ekstreme eller berusede șūfīer som er blevet afvist af 'mainstream' sufisme. ${ }^{9}$ For eksempel nævner al-Hujwīrī selv i sit værk tolv forskellige șūfî-grupper,

7 Udtrykket 'de skønneste navne' (al-asmā' al-husnā) bruges ofte som basis for det teologiske begreb om Guds 99 epiteter (jf. Gimaret 1988, 367-81).

8 Det kan diskuteres om det overhovedet er muligt (eller analystisk brugbart) at tale om sufisme eller sufismen. Som det fremgår af nedenstående er den islamiske mystik en mangeartet og kompleks historisk størrelse. For videre diskussion af dette spørgsmål, se fx Melchert 2014, 1996; Ogén 1982; Nicholson 1906.

9 'Mainstream' er naturligvis også et problematisk ord at sætte på et så divers fænomen som sufisme. Med 'mainstream' mener jeg her den generelle tendens til at gøre sufismen mere spiselig for andre denominationer inden for islam, en tendens som især var udtalt fra ca. år 1000. En mystiker, som ofte 
hvoraf ti af dem er accepterede. ${ }^{10}$ Iblandt de accepterede figurerer, for eksempel, gruppen Tayfūriyya (efter Abū Yazīd Țayfūr al-Bișțāmī (d. 875), se nedenfor), som netop var kendt for sin beruselsespraksis (Mojaddedi 2003, 6). Til hvilken grad en eventuel accept gik, kan naturligvis også diskuteres. Den syriske Hanbalī teolog og lovlærde Ibn Taymiyyah (d. 1328) er måske en af de mest kendte sunnī-islamiske kritikere af diverse former for sufisme (fx Meier 1981). ${ }^{11}$ Dog har Muhammad Umar Memon (og andre) argumenteret for, at Ibn Taymiyyahs forhold til sufisme generelt er blevet misforstået (Ibn Taimīya og Memon 2013, viiff.; Makdisi 1991b). Ibn Taymiyyah var formentlig, ligesom de fleste andre muslimer på dette tidspunkt, på den ene eller anden måde selv involveret $i$ et, for ham acceptabelt og uproblematisk, șūfíbroderskab (Makdisi 1991a).

Selvom typologien ikke nødvendigvis betegner faktisk beruselse, er den stadig konceptuelt set interessant, da beruselsens kilde, vin, anses som noget problematisk og urent i Koranen og den tidlige islam. I det følgende vers pointerer Koranen også, at beruselse kan påvirke gennemførelsen af de islamiske rituelle handlinger, her bønnen, og at en sådan tilstand derfor bør undgås:

I, der tror! Gå ikke til bøn, når I er berusede, uden at vide, hvad I siger (wa-antum sukārāa hattā ta 'lamū mā taqūlūna)! Eller når I er urene (wa-lā junuban); med mindre I tilfældigt kommer forbi - uden at have vasket jer! Hvis I er syge eller på rejse, hvis en af jer kommer fra nødtørftsstedet, eller hvis I har haft kønslig omgang med kvinder, og I ikke kan finde vand, så skal I gå hen til en god og tør jordbund og gnide jeres ansigt og hænder. Gud er overbærende og tilgivende. (K 4:43)

I dette koranvers gives således den korrekte udførelse af bønnen som forklaring på, hvorfor beruselse og senere vin forbydes. ${ }^{12}$ Vin omtales dog ikke direkte som noget urent her, hvor der anvendes en mere overordnet semantisk kategori for urenhed, nemlig igennem termen junub 'tilsmudset, udelukket' (Ambros 2004, 62; Reinhart 1990, 3ff.). Argumentet om, at vin er urent og kan forhindre bønnens udførelse, fremgår mere direkte af den følgende passage, som tænkes at være Koranens endelige forbud mod vin: ${ }^{13}$

trækkes frem som repræsentant for denne tendens, er Abu 1-Qasīm al-Qushayrī (d. 1072) (alQushayri 2007; jf. også Melchert 1996).

10 Hvorvidt disse grupper er faktiske historiske șūfī-grupper fra al-Hujwīin̄is tid, kan og er blevet debatteret (jf. Mojaddedi 2003, 6ff.).

11 Den islamiske mystiks forhold til forskellige sunnī-islamiske fremtrædelsesformer er en længere diskussion og vil være uden for denne artikels rækkevidde. Det er dog vigtigt at huske, at sufisme ikke er en sekterisk retning inden for islam, ligesom skellet mellem fx sunnīsme og shī î̀sme. Man kan således uden problemer - og de fleste muslimer har nok historisk set gjort således - være sunnī- eller shī'a-muslim og tilhøre et șūfī-broderskab.

12 Det er fra vers som dette, men især den følgende passage K 5:90-91, at de senere islamiske lovskoler argumenterede for et generelt alkoholforbud (ofte igennem den såkaldte analogimetode (qiyās)). Der findes dog forskelle imellem de fire autoritative sunnī-islamiske lovskoler (Hanafī, Mālikī, Shāfi 'ī og Hanbalī) i forhold til dette spørgsmål. For eksempel mener Hanafī, at Koranen ikke forbyder alle berusende midler, men kun dem der deler karakteristika med vin (khamr) (Hallaq 2009, 22-27).

13 Koranen indeholder tre passager om vin, som relaterer sig til dette spørgsmål. Den første (K 16:67) synes at tillade vin, den anden (K 2:219) indtager en mellemposition, og det sidste (K 5:90-91), som citeres her, udtrykker et klart forbud. Disse blev harmoniseret i de senere islamiske lovtraditioner 
I, der tror! Vin (l-khamru), hasardspil, offersten og orakelpile er urent (rijsun) og af Satans værk. Undgå det (fa-jtanibūhu)! Måske vil det gå jer godt! Ved vin og hasardspil ønsker Satan kun at stifte fjendskab og had mellem jer og at afholde jer fra ihukommelsen af Gud og fra bønnen (wa-yașuddakum 'an dhikri l-lāhi wa-'ani l-șalati). Vil I holde inde? (K 5:90-91)

Udover at vin bør undgås, fordi det afholder de troende fra den korrekte tilbedelse af Gud, fra ihukommelse og bøn, kategoriseres vin i dette vers som noget direkte urent. Urenhedens semantik fremgår her fra det arabiske ord rijs 'snavs, noget der er beskidt', som forekommer i alt ti gange i den koraniske tekst. ${ }^{14}$ Udover at betegne vin, hasardspil, offerstene og orakelpile (K 5:90) bruges rijs i Koranen i omtalen af svinekød (K 6:145), de såkaldte 'hyklere' (munāfiqūn; K 9:95), de vantro (K 9:125) og idolerne (K 22:30, se nedenfor). Beruselse er ikke nævnt her, men kan i sammenhæng med K 4:43 citeret ovenfor ses som en naturlig (uren) konsekvens. En anden central term for urenhed er najas 'smuds, snavs' som kun forekommer en enkelt gang i K 9:28 (Ambros 2004, 263):

I, der tror! De, der sætter andre ved Guds side, er urene (innamā l-mushrikūna najasun). Lad dem ikke komme i nærheden af det fredhellige bedehus, når dette år er omme! Hvis I frygter fattigdom; - Gud kan gøre jer rige af sin overflod, hvis Han vil. Gud er vidende og vis.

I dette vers karakteriseres endnu en koranisk gruppe igennem urenhed, nemlig 'dem der associerer' eller 'dem der sætter andre ved Guds side' (mushrikūn) (jf. Crone 2012, 2013; Hawting 1999). Den urene reference kan diskuteres: Indikerer verset at 'associatorerne' i sig selv er urene og derfor ikke bør tilgå de hellige områder omkring Ka baen, eller at de generelt bør undgås, ligesom urene ting og substanser bør undgås? (Nasr m.fl. 2015, 512). Som vi vil se, handler kategorierne, de berusede versus de ædru șūfīer, især om praksis; men typologien kan ligeledes tænkes at betegne en basal skelnen imellem noget urent og noget rent.

Inden for de islamiske șūfî-traditioner er især to figurer forbundet med mystiske erfaringer af beruselse, nemlig de to persiske mystikere Abū Yazīd al-Bișțāmī (d. 875) og al-Ḥusayn b. Manșūr al-Ḥallāj (d. 922). Både al-Bișțāmī og al-Ḥallāj er berømte - og berygtede - for at komme med såkaldte shațh-udtalelser, dvs. ekstatiske udtalelser som har en ekstrem eller skandaløs karakter (Knysh 2000, 70; Ernst 1985). Al-Bișțāmīs mest omdiskuterede shaṭh-udtalelse er formentlig subhān̄i eller 'Lovprisningen tilkommer Mig', hvor det for al-Hallāj gælder udsagnet anā l-haqq eller 'jeg er Sandheden' (Knysh 2000, 75; Massignon 1982, 64ff.). Begge ytringer kan opfattes problematiske og ligefrem, for dem der står uden for sufismen, blasfemiske, da de begge indikerer at al-Bișțāmī og al-Hallāj så sig selv som guddommelige eller ligefrem som Gud. Subḥ̄n̄ì er et udtryk, der udelukkende bruges om Gud og al-haqq 'sandheden' er ét af

igennem den såkaldte naskh eller abrogationsteori. Med basis i en kronologisk opdeling af Koranen går naskh ud på, at senere åbenbarede vers kan erstatte tidligere åbenbarede vers i påbud. I forhold til vinspørgsmålet ender K 5:90-91 således med at være det vers der gælder. For yderligere information om naskh, se Burton 1970; Madigan 2001 187-191.

14 Ifølge Arne A. Ambros $(2004,108)$ betyder roden $r-j-s:$ "filth (used only metaphorically, to characterize unlawful matters)". 
Guds tilnavne (K 3:191; 22:6, se note 6). Den almindelige eller ikke-indviede muslim kan således opfatte en sådan udtalelse som en handling af shirk, det at associere noget med Gud, som opfattes som noget af det mest syndige og urene inden for islam (jf. K 9:28 citeret ovenfor og måske også al-Ḥallājs hemmelighedskræmmeri i den indledende anekdote). I sufisme generelt, og for disse radikale șūfīer især, er der er således en intrikat balance mellem shirk og foreningsretorikken ( $f x$ via det ovennævnte begrebspar fana' 'forsvinden i Gud' og baqa' 'forbliven'). Mange șūfīer er derfor blevet kritiseret for, for eksempel, at tale for en inkarnation med Gud, altså at man i foreningen bliver noget guddommeligt. Șūfier selv forklarer foreningen mere som en umiddelbar gudsoplevelse, hvor subjektet, det menneskelige selv, momentant udslettes, og ikke som en faktisk forening (Ohlander 2014). Den senere definition af en shathudtalelse indebærer også, at det er ikke noget, som șūfien kan stilles til ansvar for: Udtalelsen er ikke șūfiens egen vilje, men Guds (Ernst 1985, 117ff.). En sådan løsning eksemplificerer hvordan selv umiddelbart blasfemiske udtalelser kan inkorporeres og accepteres - $\mathrm{i}$ hvert tilfælde til en vis grad - af mainstream systemet gennem forhandling, revision og kompromiser.

Det var ikke kun al-Ḥallājs udtalelser, som blev anset som problematiske. Ifølge fotællingerne gennemførte han også ekstreme asketiske praksisser, der blandt andet inkluderede et år alene foran Ka'baen i Mekka i stilhed og faste med det mål at angre og komme tættere på Gud. Her nægtede han angiveligt at rituelt rense sig, selvom han befandt sig foran islams mest centrale helligdom (jf. K 9:28 citeret ovenfor hvor folk kan nægtes adgang til det hellige område hvis de er urene). Ifølge diverse kilder skulle al-Hallāj også have bygget en model af Ka'baen foran sit hus i Baghdad, som han circumambulerede når der var hajj (Massignon 1982; Knysh 2000, 73-74, jf. Christiansen 2017). Af disse (og flere andre) grunde blev han fordømt og afvist, ikke kun af de sekulære og religiøse eliter, men også af andre mere konservative șūfier. Deres afstandtagen har formentlig haft noget at gøre med, at al-Ḥallāj insisterede på at prædike i offentlighed, noget som de konservative șüfier mente, at man skulle holde sig fra (Massignon 1982, 117ff.).

I sidste ende blev al-Hallāj stillet til ansvar for sine udtalelser og berusede (og måske urene) virke. Historien om hans henrettelse for kætteri i Baghdad i 922 argumenteres ofte som at markere et vigtigt skift i sufismen og måske i den bredere islams historie (Knysh 2000, 72). Historien om al-Ḥallājs - hvis autenticitet kan diskuteres illustrerer en dramatisk splittelse imellem de sunnì-lærde ('ulam $\bar{a}$ ') og de individuelle - men meget populære - șūfîer. Hvorfor og på hvilken endelig anklage al-Hallāj blev henrettet, debatteres stadig. Selvom han blev fængslet i 913 blev hans dødsdom først udført i 922, angiveligt efter utallige forsøg på at få ham frifundet (Massignon 1982, 157ff.). Interessant for os her er nogle af de legendariske elementer forbundet til fortællingen om hans henrettelse. For eksempel skulle viziren af Baghdad på dette tidspunkt angiveligt have overtalt kaliffen om henrettelsens udførelse med det følgende argument:

Hvis han ikke bliver henrettet, vil han ændre den religiøse lov, og alle vil blive frafaldne på grund af ham. Dette vil uvægerligt føre til din stats tilintetgørelse (min oversættelse fra Knysh 2000, 77). 
Eller den følgende bekendtgørelse fra al-Hallājs anklagere lige før han blev henrettet:

Dette gøres for islams skyld; lad hans blod være på vore hoveder (min oversættelse fra ibid.).

I legenderne om al-Ḥallāj er det således for islams skyld, at hans liv og praksis må ophøre. Al-Hallāj gik for vidt i sin anomiske og detabiliserende praksis og kunne ikke accepteres - i hvert tilfælde ikke af dem, der endte med at have magt og gennemføre hans dødsdom. For de berusede șūfīer førte anomisk praksis således til frelse, men om deres søgen også var karakteriseret af urenhed kan diskuteres yderligere. AlHallājs virke eksemplificerer under alle omstændigheder et centralt spørgsmål for dette temanummers emne: Til hvilket grad kan anomisk og uren praksis accepteres?

\section{Et $u$ oplagt eksempel}

Jeg vil nu vende tilbage til Koranen og mit udvalgte uoplagte eksempel. I det ovenstående afsnit har jeg præsenteret tre termer (junub, rijs og najas) for former for urenhed i Koranen. ${ }^{15}$ I den følgende passage fra sura 22 (sūrat l-hajj eller 'Valfarten') fremkommer endnu en relevant term:

27. Kald til valfarten (bi-l-hajji) blandt menneskene, så de kommer til dig til fods og på hver en mager kamel gennem hvert et dybt bjergpas,

28. for at de kan se fordelene for sig selv og på bestemte dage udtale Guds navn over de stykker kvæg, som Han har forsørget dem med! Spis deraf, og giv den fattige stakkel noget at spise!

29. Derefter skal de gøre en ende på deres uplejede ydre (thumma l-yaqd̦̄̄ tafathahum), opfylde deres løfter (wa-l-yūfū nudhūrahum) og gå rundt om det ældgamle hus (wa-lyațtawwafū bi-l-bayti l-'atìqi).

30. Sådan skal det være (dhālika). Det vil være godt for den, der holder Guds ukrænkelige ting i ære, hos hans Herre. Alt kvæg er jer tilladt, bortset fra det, hvorom I har fået læst op. Undgå afgudsbilledernes smuds (fa-jtanibu l-rijsa mina l-awthāni), og undlad at føre usand tale!

Passagen omhandler den islamiske pilgrimsfærd hajj og nævner nogle af de elementer, som senere bliver en fast del af dette ritualkompleks. ${ }^{16}$ I vers 29 forekommer udtrykket 'deres uplejede ydre' igennem det arabiske substantiv (med et possessivt pronomen for 3. person maskulinum pluralis 'dem' eller 'deres') tafathahum fra roden $t$ $f$-th. Bemærk at passagen også indeholder en meget materiel beskrivelse af shirk i 'de

15 For litteratur om hvordan disse tre termer bruges i det senere (og komplekse) islamiske renhedssystem (țahāra), se Reinhart 1990; Lowry 2001; Katz 2002.

16 Koranen varierer med hensyn til hvor mange detaljer der gives omkring de forskellige islamiske ritualer. Hvor fx fasten i Ramaḍān-måneden er forholdsvis detaljeret beskrevet (K 2:183-187), er selve den rituelle bøn kun indikeret (K 17:78-79). Hvordan og hvornår de islamiske ritualer blev fastlagt, bliver stadig debatteret (jf. fx Kister 1979, 3-6; Tottoli 1998; Halevi 2007; Böwering 2001; Christiansen 2017). 
beskidte idoler' ('afgudsbilledernes smuds' i Wulffs oversættelse af vers 30). Igen understreges det, hvordan det at associere, opfattes som noget urent (rijs). Med samme frase som i K 5:90 citeret ovenfor er idolerne og deres urenhed noget, der skal 'undgås' (fa-jtanibu l-rijsa). Vers 29 indeholder to yderligere påbud, nemlig at de troende skal 'opfylde deres løfter' og udføre țawāf, circumambulere Ka 'baen (jf. Christiansen 2017).

Udtrykket tafathahum eller 'deres uplejede ydre' er et hapax legomena i Koranen, dvs. det forekommer kun én gang i teksten, og diskuteres derfor også i stor udstrækning i den islamiske eksegetiske tradition. Denne diskussion kan tilgås på flere måder. For eksempel kan det være brugbart at sammenligne forskellige koranoversættelser af dette ord og sætning i K 22:29:

- Ellen Wulf (2006): “Derefter skal de gøre en ende på deres uplejede ydre (thumma l-yaqdū tafathahum), opfylde deres løfter (wa-l-yūfū nudhūrahum) og gå rundt om det ældgamle hus (wa-l-yatțawwafü bi-l-bayti l- 'atīqi) [...]"' (som citeret ovenfor).

- Muhammad Marmaduke Pickthall (1930): “Then let them make an end of their unkemptness and pay their vows and go around the ancient House" (Pickthall 1930, 29).

- Arthur A. Arberry (1955): “Let them then finish with their self-neglect and let them fulfil their vows, and go about the Ancient House."(Arberry 1983, 336)

- 'Abdullāh Yūsuf 'Alī (1934): "Then let them complete the rites prescribed for them, perform their vows, and (again) circumambulate the Ancient House" (Yūsuf 'Alī 2003, 334).

En anden tilgang er at jævnføre diverse ordbøger for betydninger af den specifikke rod:

- Ambros (2004): “tafath approx. 'unkemptness', ref. to the neglected condition of the body due to abstaining, as required by the ritual of the pilgrimage, from shaving, clipping the nails, anointing o.s., etc. (22/29)" (Ambros 2004, 50).

- Edward William Lane (1863-93): “He left off, or abstained from, anointing himself, and shaving his pubes, and in consequence became dirty [...] signifies the state of being dirty [...] the state of having matted and dusty hair, or a dusty head, long left unanointed [...]it signifies the shaving and shortening, or clipping of the beard and mustache and (the hair of) the armpit [...] (Lane 1968, Book I, 308).

- John Penrice (1876): “To perform the sacred rites at Mecca; also, to cleanse [...] Two interpretations are given of this word; according to one it means filth, and according to the other, the observance of certain rites and ceremonies imposed upon the Pilgrims at Mecca, among which were cleansing the person, 
shaving etc. Thus the phrase $22 \mathrm{v} .30$ may mean: 'Let them put an end to their want of cleanliness,' or 'Let them complete the rites'" (Penrice 2011, 23). ${ }^{17}$

Fra disse forskellige oversættelser og ordbøger fremgår det, at der er to betydninger og fortolkninger af udtrykket tafathahum: 1) At det betyder fysisk selvforsømmelse eller upleje, karakteriseret af en vis form for naturlig urenhed og formentlig et resultat af en periode i ihrām-tilstanden (se nedenfor); 2) At der er nogle bestemte ritualer, som er bundet til dette tidspunkt i pilgrimsfærdens ritualkompleks (en fortolkning der ikke nødvendigvis udelukker den førnævnte).

Mange eksegeter tolker dette vers til at omhandle $i h r a \bar{m} m$, den hellige og rituelt anderledes tilstand som en muslim skal være i i forbindelse med hajj eller 'umra (jf. fx Nasr m.fl. 2015, 836-37). Ordet iḥrām (IV) kommer fra den arabiske rod hh-r-m, som også danner basis for det mere kendte arabiske ord harām 'forbudt' eller 'hellig'. Formen ihrām forekommer ikke i Koranen; men det gør derimod hurum, som betyder at være i en tilstand af ihrām. Både sura 5 (sūrat al-mā ida) vers 1 og passagen 95-96 beskriver forskellige ting som er forbudte, hvis man er i en tilstand af $i$ hrām eller som Wulff oversætter det, 'viet til valfart' (wa-antum hurumun) (Wulff 2006, 86, 97; Ambros $2004,70)$. I den senere islamiske tradition og praksis indebærer tilstanden, at den mandlige muslim først skal tage et bad og bede nogle bestemte bønner, før han iklæder sig en hvid dragt, der blandt andet er uden søm for at fjerne alle eventuelle markeringer af status (Martin 2005; Peters 1994, 114ff.). Kvinder må derimod beholde deres eget tøj på, så længe det er simpelt (formentlig også for at fjerne indikatorer på social status), men bør ikke have ansigtet eller håret dækket af slør. ${ }^{18}$ Mens man er i en tilstand af iḥām, må man ikke føre 'lidenskabelig tale', og sex er også forbudt (K 2:197), der er ingen strid, jagt (K 5:2) eller 'gudløshed' (fusūq), man må ikke bruge nogen former for parfume eller dufte, man må ikke barbere sig eller klippe sit hår (K 2:196), ej heller klippe negle. I ordbogsopslagene ovenfor tilføjes andre detaljer såsom forbud mod moustache-trimning og kønshårbarbering. I ịhrām ligger således en fysisk selvforsømmelse ('det uplejede ydre'), som ofte forklares med at fokus i stedet bør være på sjælepleje, samt at det er en praktisk erfaring som kan bruges i mange andre aspekter af livet (Martin 2005). K 22:29 synes derfor at handle om ihrām-tilstandens ophør: Der skal gøres en ende på det uplejede ydre, der skal vendes tilbage til det normale. Denne tilbagevenden indikeres i versets andet påbud: Opfyldelsen af løfter. Og måske kan netop dette påbud tolkes som en allusion til den i indledningen omtalte fitra-tanke. Som vi har set er det netop de soignerende handlinger forbundet med fițra som forbydes i ihrām-tilstanden. Med andre ord, i ihrām-tilstanden, som den liminale markør den er, opgives idealer om kropspleje og hygiejne til fordel for at

17 Det komplekse forhold imellem et originalsprog, dets oversættelse og tolkning vil ikke blive inddraget yderligere her. Inden for den islamiske tradition har det flere gange været argumenteret at Koranen slet ikke kan (og bør) oversættes. Det eneste jeg vil bemærke, og som fremgår fra de angivne eksempler, er at en oversættelse altid en tolkning. For en artikel der fremlægger Koranens oversættelsesproblematikker i forhold til forskellige ideologiske og sekteriske agendaer, se Robinson 1997.

18 Det så omdiskuterede islamiske slør var formentlig oprindeligt et statussymbol (K 33:53, 59, jf. Siddiqui 2001). 
indgå i anomien. Når ihrām-tilstanden ophører skal den troende, igennem en fornyet fokus på kropspleje, vende tilbage til og genbekræfte sin oprindelige pagt med Gud, det kulturelle, antropocentriske og ordnede nomos.

\section{To former for 'urenhedsfetichisme'}

De to cases behandlet her eksemplificerer forskellige versioner af lighedstegnet mellem forløsning og anomi som former for urenhed. Hvor de tidlige berusede șūfīer og deres radikale udtalelser og praksisser måske mere tydeligt illustrerer hvordan anomi og urenhed søges og påtages, kan ihrām-tilstanden også tolkes som form for positiv, men dog liminal, flirten med urenhed. Denne tilstand repræsenterer en temporær udstigning fra det normale, måske endda fra fițra. En sådan udstigning er især kendt i arkaiske religioner - også i forhold til rituelle forløb - og her tænkes det anomiske som en støtte til nomien. Der vendes tilbage til kaos, det naturlige, det urene for at bekræfte og styrke den givne orden, det kulturelle, det normale. I det aksiale ideal derimod skal nomos, den jordiske verden eller den arkaiske verdensorden, benægtes. Jeg vil derfor forslå, at introducere et brugbart skel i forhold til det overordnede emne, nemlig 'temporær' versus (hvad man måske kan kalde for) 'permanent urenhedsfetichisme'. Hvor de fulde șūfier, og formentlig andre 'hellige mænd' inden for islam, søgte en mere permanent anomi - måske karakteriseret af et fokus på urenhed - og prædikede at det var vejen til menneskets frelse, var ihrām-tilstanden en temporær og kontrolleret exit fra og entry tilbage til det normale system. Koranens urenhedskompleks synes derfor at have gennemgået en re-arkaisering, hvor det er udelukkende i liminalitet at der kan flirtes med det urene. På alle andre tidspunkter er urenhed i dens diverse koraniske former noget der skal undgås. I det post-aksiale kompromis, den komplekse og til tider konfliktuelle sammenblanding af arkaiske og aksiale elementer (Bellah 2011, 523; Lundager Jensen 2013, 28-30), og som Koranen og den tidlige islam især eksemplificerer, er en sådan temporær udstigning således en samtidig bekræftelse og benægtelse af nomos som i sig selv er modsigende. Men det er denne selvmodsigelse som er kompromisets styrke - det er komplekst, spændingsfyldt og komplimentær - og styrker systemets (hvad end det er) fortsatte eksistens. Systemer (og religioner) er derfor altid under revision: De er dynamiske, i spænding, og aldrig i stilstand. Så måske de fulde șūfier er det tætteste vi kommer på den aksiale benægtelse af den arkaiske verden og en permanent urenhedsfetichisme i den tidlige islam. Men også her revideres både interne og eksterne holdninger til deres praksis konstant. Historien om al-Hallāj, som gik for vidt, i hvert tilfælde ifølge visse dele af hans samtid, er et udmærket eksempel på denne dynamiske forhandlingsproces.

I denne artikel har jeg, igennem hvad jeg har kaldt en trial-and-error-process, præsenteret to cases fra islam, som kan være relevante i forhold emnet Forløsning igennem urenhed (anomisk praksis). Et videre studie af radikale șūfīer, ikke kun de berusede, vil formentlig tilføje yderligere vægt til deres rolle som urenhedssøgende figurer i den tidlige islamiske periode. Koranen derimod indeholder ikke materiale, som udtalt eksemplificerer en frelsestanke med udgangspunkt i permanent urenhed eller anomisk 
praksis. Det kan skyldes, at Koranen er en forholdsvis sen tekst, som allerede fra sin begyndelse var et tydeligt post-aksialt kompromis. Selvom Koranen naturligvis ender med at fastsætte en ny norm (og på ingen måder kan ses som uren), kan den, som i dens samtids nytænkede og normbrydende stykke litteratur den er, dog selv forstås som anomisk. Anomi er jo netop, ligesom det aksiale ideal, ikke noget der kan bevares i særlig lang tid. Anomi transformeres til nomos og det aksiale til det post-aksiale.

\section{LITTERATUR}

Ahlwardt, Wilhelm

1861 Diwan des Abu nowas, I, Die Weinlieder, Greifswald: C.A. Koch's Verlagsbuchhandlung.

Al-Qushayri, Abu 1-Qasim

2007 Al-Qushayri's Epistle on Sufism: Al-Risala al-qushayriyya fi 'ilm al-tasawwuf, oversat af Alexander D. Knysh. Reading: Garnet Publishing.

Ambros, Arne A.

2004 A Concise Dictionary of Koranic Arabic, Wiesbaden: Reichert Verlag.

Arberry, Arthur J.

1983 The Koran Interpreted: A Translation by A.J. Arberry, Oxford: Oxford University Press (1955).

Bellah, Robert N.

2005 "What is Axial about the Axial Age?", European Journal of Sociology / Archives Européennes de Sociologie 46 (01): 69-89. https://doi.org/10.1017/S0003975605000032

2011 Religion in Human Evolution: From the Paleolithic to the Axial Age, Cambridge: Belknap Press. https://doi.org/10.4159/harvard.9780674063099

Bellah, Robert N., \& Hans Joas, eds.

2012 The Axial Age and Its Consequences, Cambridge: Belknap Press. https://doi.org/10.4159/harvard.9780674067400

Bräunlein, Peter J.

2016 "Thinking Religion Through Things: Reflections on the Material Turn in the Scientific Study of Religion $\backslash s^{\prime \prime}$, Method $\mathcal{E}$ Theory in the Study of Religion 28 (4-5), 365-99.

Burton, John

1970 "Those are the High-flying Cranes", Journal of Semitic Studies 15 (2), 246-265. https://doi.org/10.1093/jss/15.2.246

Böwering, Gerhard

2001 "Prayer", EQ (Encyclopaedia of the Qur'ān). https://doi.org/10.1163/1875-3922_q3_EQCOM_00155

Christiansen, Johanne Louise “'Stay up during the night, except for a little' (Q 73:2): The Qur'ānic Vigils as Ascetic Training Programs", Religion (under udgivelse).

The Exceptional Qur'an: Flexible and Exceptive Rhetoric in Islam's Holy Book. Islamic History and Thought, Gorgias Press (under udarbejdelse).

2017 “'Deres bøn ved Huset består kun af fløjten og klappen i hænderne’ (sura 8:35): Forhandling og strategier om procession i Koranen", Religionsvidenskabeligt Tidsskrift 66: 105. https://doi.org/10.7146/rt.v0i66.26449

Christiansen, Johanne Louise \& Katrine Boserup Jensen "'I would just light a fire in my backyard and burn it' (imām from Arab mosque in Denmark, 2018): A Qualitative Study of the Qur'an as a Holy Artefact in Denmark" (under udarbejdelse).

Cook, Michael

2000 The Koran. A Very Short Introduction. Oxford: Oxford University Press. 
https://doi.org/10.1093/actrade/9780192853448.001.0001

Crone, Patricia

2012 "The Quranic Mushrikūn and the Resurrection (Part I)", Bulletin of the School of Oriental and African Studies 75 (3): 445-72. https://doi.org/10.1017/S0041977X12000584

2013 "The Quranic Mushrikūn and the resurrection (Part II)". Bulletin of the School of Oriental and African Studies 76 (1): 1-20. https://doi.org/10.1017/S0041977X12000596

Crone, Patricia \& Michael Cook

1977 Hagarism: The Making of the Islamic World, Cambridge: Cambridge University Press.

Douglas, Mary

1966 Purity and Danger, London: Routledge \& Kegan Paul.

Durkheim, Emile

1984 The Division of Labour in Society, London: Macmillan (1893).

Ernst, Carl W.

1985 Words of ecstasy in Sufism, Albany: State University of New York Press.

Gimaret, Daniel

1988 Les noms divins en Islam: exégèse lexicographique et théologique, Paris: Editions du Cerf.

Halevi, Leor

2007 Muhammad's Grave: Death Rites and the Making of Islamic Society, New York: Columbia University Press.

Hallaq, Wael B.

2009 An Introduction to Islamic Law, Cambridge: Cambridge University Press. https://doi.org/10.1017/CBO9780511801044

Hawting, Gerald R.

1999 The Idea of Idolatry and the Emergence of Islam. From Polemic to History, Cambridge: Cambridge University Press. https://doi.org/10.1017/CBO9780511497490

Hoffmann, Thomas \& Johanne Louise Christiansen

"Flertydighed og præcision i Koranen", CHAOS 69 (under udgivelse (a)).

"Paradoxes, Loopholes, and Invitations in Qur'ānic Polemic", Conference Proceedings (under udgivelse (b)).

Ibn Taimīya, Ahmad Ibn-'Abd-al-Halim, og Muhammad Umar Memon

2013 Ibn Taimīya's Struggle Against Popular Religion, With an Annotated Translation of His Kitäb iqtid̄ā' aș-șirāt al-mustaqīm mukhālafat așhāb al-jahìmm, Berlin, Boston: De Gruyter. https://doi.org/10.1515/9783111662381

Jaspers, Karl

1949 Vom Ursprung und Ziel der Geschichte, Zürich: Artemis.

Kamali, Mohammad Hashim

2015 The Middle Path of Moderation in Islam: The Qur'änic Principle of Wasatiyyah, Oxford: Oxford University Press. https://doi.org/10.1093/acprof:oso/9780190226831.001.0001

Katz, Marion H.

2002 Body of Text: The Emergence of the Sunnī Law of Ritual Purity, Albany: State University of New York Press.

Kister, M. J.

1979 "Some Reports Concerning al-Ṭā' if", Jerusalem Studies in Arabic and Islam 1, 1-18.

Knysh, Alexander

2000 Islamic Mysticism: A Short History, Leiden: Brill.

Lane, Edward William

1968 An Arabic English Lexicon 1-8, 8 bd., Beirut: Libraire du Liban (1863-1893).

Lowry, Joseph E.

2001 "Ritual Purity", EQ (Encyclopaedia of The Qur'ān). https://doi.org/10.1163/1875- 


\section{2_q3_EQCOM_00178}

Lundager Jensen, Hans J.

2013 "Robert Bellah, religion og menneskelig evolution", Religionsvidenskabeligt Tidsskrift 60, 11-31. https://doi.org/10.7146/rt.v0i60.20408

2019 "Igennem urenhed til himlen: Den tanato-kosmologiske transformation fra israelitisk religion til kristendom", Religionsvidenskabeligt Tidsskrift 69, 7-29.

McDonald, D.B.

1960- “Fițra”, EI² (Encyclopaedia of Islam). https://doi.org/10.1163/1573-3912_islam_SIM_2391

Madigan, Daniel A.

2001 The Qur'ân's Self-Image: Writing and Authority in Islam's Scripture, Princeton: Princeton University Press.

Maghen, Ze'ev

2012 After Hardship Cometh Ease: The Jews as Backdrop for Muslim Moderation, Berlin: Walter de Gruyter.

Makdisi, George

1991a "Ibn Taymiyya: A Study of the Qadiriya Order", in: Religion, Law and Learning in Classical Islam. Britain: Variorum.

1991b “The Hanbali School and Sufism”, in: Religion, Law and Learning in Classical Islam, 115-26. Britain: Variorum.

Martin, Richard C.

2005 “Pilgrimage: Muslim Pilgrimage”, in: Lindsay Jones, ed., Encyclopedia of Religion, , 2nd ed., 10:7154-61. Detroit, MI: Macmillan Reference USA.

Massignon, Louis

1982 Hallāj: Mystic and Martyr. Princeton, NJ: Princeton University Press (oversættelse af Passion de Husayn Ibn Mansûr an-Hallâj fra 1922).

Mazuz, Haggai

2012 "Menstruation and Differentiation: How Muslims Differentiated Themselves from Jews Regarding the Laws of Menstruation", Der Islam 87, 204-223. https://doi.org/10.1515/islam-2011-0029

Meier, $\mathrm{F}$

1981 “Das Sauberste über die Vorbestimmung. Ein Stück Ibn Taymiyya”, Saeculum 32: 74-89. https://doi.org/10.7788/saeculum.1981.32.1.74

Melchert, Christopher

1996 "The Transition from Asceticism to Mysticism at the Middle of the Ninth Century C.E.", Studia Islamica, nr. 83: 51. https://doi.org/10.2307/1595736

2014 "Origins and Early Sufism", in: Lloyd Ridgeon, ed., The Cambridge Companion to Sufism, 3-23. New York: Cambridge University Press. https://doi.org/10.1017/CCO9781139087599.003

Mojaddedi, Jawid A.

2003 "Getting drunk with Abū Yazīd or staying sober with Junayd: the creation of a popular typology of Sufism", Bulletin of the School of Oriental and African Studies 66 (1), 1-13. https://doi.org/10.1017/S0041977X03000016

Muslim ibn al-Hajjāj al-Naysāburi Sahīh Muslim. www.sunnah.com. Tilgået 08.01.2019.

Nasr, Seyyed Hossein m.fl.

2015 The Study Quran: A New Translation and Commentary, New York: Harper One.

Nicholson, Reynold A.

1906 "A Historical Enquiry concerning the Origin and Development of Sufiism: With a List of Definitions of the Terms 'Șúfí and 'Tașawwuf,' Arranged Chronologically", Journal of the Royal Asiatic Society of Great Britain and Ireland, 303-48. https://doi.org/10.1017/S0035869X00034353 
Ogén, Göran

1982 "Did the term 'ṣūfí' exist before the Sufis?", Acta Orientalia 43, 33-48.

Ohlander, Erik S.

2014 "Early Sufi Rituals, Beliefs, and Hermeneutics", in: Lloyd Ridgeon, The Cambridge Companion to Sufism, New York: Cambridge University Press, , 53-73.

https://doi.org/10.1017/CCO9781139087599.005

Penrice, John

2011 A Dictionary and Glossary of the Koran, Mineola, N.Y: Dover Publications (1876).

Peters, F. E.

1994 The Hajj: The Muslim Pilgrimage to Mecca and the Holy Places, Princeton, NJ: Princeton University Press.

Pickthall, Marmaduke W.

1930 The Meaning of the Glorious Koran: An Explanatory Translation, London: A.A. Knopf.

Rappaport, Roy A.

1979 Ecology, Meaning, and Religion, Richmond, CA: North Atlantic Books.

Reinhart, A. Kevin

1990 “Impurity/No Danger”, History of Religions 30 (1), 1-24. https://doi.org/10.1086/463212

Ritter, H. \& Bausani, A.

1960 “Djalāl al-Dīn Rūmī”, EI² (Encyclopaedia of Islam). https://doi.org/10.1163/1573-

3912_islam_COM_0177

Robinson, Neil

1997 "Sectarian and Ideological Bias in Muslim Translations of the Qur'ān", Islam and ChristianMuslim Relations 8 (3), 261-278. https://doi.org/10.1080/09596419708721126

Siddiqui, Mona

2001 “Veil”, EQ (Encyclopaedia of The Qur'ān). https://doi.org/10.1163/1875-3922_q3_EQSIM_00441

Tottoli, Roberto

1998 "Muslim Attitudes Towards Prostration (sujūd): I. Arabs and Prostration at the Beginning of Islam and in the Qur'ān", Studia Islamica (88), 5-34. https://doi.org/10.2307/1595695

Wansbrough, John

1977 Quranic Studies: Sources and Methods of Scriptural Interpretation, Oxford: Oxford University Press.

Wulff, Ellen, overs.

2006 Koranen, København: Forlaget Vandkunsten.

Yūsuf 'Alī, 'Abdullāh

2003 The Meaning of the Holy Qur'ān, Markfield: The Islamic Foundation (1934).

Zadeh, Travis

2008 "'Fire Cannot Harm It': Mediation, Temptation and the Charismatic Power of the Qur'an". Journal of Qur'anic Studies 10 (2), 50-72. https://doi.org/10.3366/E1465359109000412

Johanne Louise Christiansen, postdoc, ph.d. Afdeling for Bibelsk Eksegese, Det Teologiske Fakultet, Københavns Universitet jch@teol.ku.dk 